\title{
II. OUTDOOR WORK IN MICHIGAN
}

By William M. Bryant,

Chairman, County Road Commission, Kalamazoo County, Mich.

Tramps and vagrants were a serious problem in Kalamazoo county - so serious that in 1908 the sheriff reported a total of 3,546 commitments. This was probably due to the fact that Kalamazoo was a wet county, surrounded by dry counties, and to it drifted many thirsty men who became hilarious and received from ten to sixty days' sentences. These, as a rule, were so-called one-term men and after their sentence expired they returned home or drifted to some other city, but their numbers made welcome the request of the Road Commission that county prisoners be worked on the public roads. The commission claimed that road-work would have a good effect on petty crime, and would eliminate the tramp nuisance, and, though this seemed a strong prediction, a deputy sheriff was appointed, given charge of the men and preparations were made to begin the work at once.

A squad of from fifteen to eighteen men was placed on the roads near the city, and brush, stumps, stone and other obstructions removed. When these roads were finished, the prisoners were taken out into the township, nearly ten miles from the city. Here two miles of brush along the highway was cut and burned and considerable ditching done. A house was rented and stoves, cots, bedding and other necessary articles installed. The prisoners were boarded at a nearby farm-house. At first the commissioners expected to work two crews of from fifteen to twenty men each, but decided to wait a few weeks to see what the results would be with one crew. The results were almost instantaneous. The news soon spread that Kalamazoo, known as one of the best feeding grounds between the two oceans, was a poor place at which to stop. After two months, the population at the jail had become so small that the road-gang was called in, and preparations made for making tile. Four men are needed at this work to keep it running smoothly. Part of the time but two prisoners were available, and the deputy sheriff had to act as third and fourth man. Three four-ton cement rollers were made, also a 
twenty-eight-foot bunk house, warmed by a stove and well lighted, and with bunks on each side which would house eighteen men.

The outlook the following spring was not promising as to help from county prisoners; the jail was practically empty, and only one camp could be maintained with prisoners. Even at this camp, it was necessary, nearly all the time, to hire extra men, as the number of prisoners was too small to supply the dozen shovelers needed. Preference in hiring this outside labor was always given to discharged prisoners who had been good workers, in fact, the best help obtainable for such work. Two of the daily papers have generously contributed papers to this camp, and a public appeal brought in a large number of the best magazines.

Guarding the men so employed has not presented many diffculties. A few, during the early spring months, walked away, but an extra thirty days' sentence by the circuit judge overcame any inclination of that sort. Good food and good treatment have made the men respond readily to any call from the superintendent; and after serving their sentence, they come out clear-eyed, with hardened muscles and good appetites, willing to do men's work.

A comparison of the sheriff's book showed that for the months of November, December, January, February and March, the first five months in which this system was given a trial, there was a decrease of over 2,300 in the number of vagrants for the corresponding months of the previous year. The jail committee's last report, which covered a period of six months, showed ten vagrants. The police report for the month of November, 1910, recorded but one arrest for vagrancy. November has usually been one of the heaviest months of the year for "gentlemen of the road."

Prisoners, as a rule, leave jail penniless; so after some discussion, the chairman proposed to pay them for one day's work for each week of good behavior. This was put into effect, and now a sixty-day man gets $\$ 12.50$ at the expiration of his sentence. A new start is thus given him.

Convict road work is a two-edged sword-it works both ways; it is a clean, moral and physical uplift for the men, and, by making use of what has been waste material, a valuable by-product is created. 